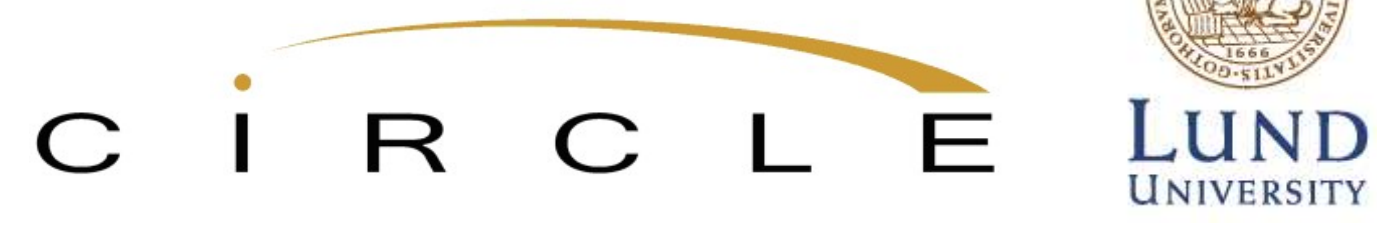

\title{
Functional procurement for innovation, welfare and the environment
}

Charles Edquist (charles.edquist@circle.lu.se)

CIRCLE, Lund University, Sweden

Jon Mikel Zabala-Iturriagagoitia (jmzabala@deusto.es)

Deusto Business School, University of Deusto, Spain

Papers in Innovation Studies

Paper no. 2020/01

This is a post-print version of a paper, which has been published in Science an Public Policy: https://doi.org/10.1093/scipol/scaa046

Centre for Innovation, Research and Competence in the Learning Economy (CIRCLE)

Lund University

P.O. Box 117, Sölvegatan 16, S-221 00 Lund, SWEDEN

http://www.circle.lu.se/publications 
WP 2020/01

\title{
Functional procurement for innovation, welfare and the environment
}

Charles Edquist, Jon Mikel Zabala-Iturriagagoitia

\begin{abstract}
Public procurement accounts for a very large share of most economies worldwide. It represents more than $15 \%$ of global GDP, which is many times larger than the world expenditures on research and development. Besides its direct purchasing power, public procurement has an enormous potential to become one of the most important missionoriented policy instruments in the context of the Sustainable Development Goals. This conceptual paper argues that the key to achieving more innovations when pursuing public procurement is to describe problems to be solved or functions to be fulfilled (functional procurement) instead of describing the products to be bought (product procurement). We contend that if products can be described in the procurement documents, it is because they exist, and hence, they cannot be regarded as innovations. Innovations cannot be described ex ante simply because they do not exist. It is therefore not accurate to talk about 'innovation procurement'. Accordingly, the only way to achieve an innovation by means of procurement is by describing the functions it is to fulfill or the problems it is to solve. For public procurement to become an effective policy instrument supporting innovation, product procurement should thus be transformed into functional procurement. Contracting authorities need to identify the problems that policy should address. The new products (innovations) solving the problems are to be designed by the potential innovators/suppliers, not by public procurers. Hence, the societal needs and problems must be translated and transformed into functional requirements. Functional procurement is allowed in EU regulations, and therefore, there are no legal obstacles to using it for innovation policy purposes. Above and beyond, the European directives recommend using functional requirements "as widely as possible". Furthermore, it leads to increased competition, not only among potential suppliers of similar products, but also among different products that solve the same problem. Functional procurement thus not only supports innovation but also serves as a powerful competition policy instrument.
\end{abstract}

Keywords: innovation policy; public procurement; product procurement, functional procurement; functional requirements; competition policy

JEL Codes: L50; O32; O33; O39

Disclaimer: CIRCLE does not take any responsibility for opinions and views expressed by the authors in this paper. 


\title{
Functional procurement for innovation, welfare and the environment
}

Accepted for publication in Science and Public Policy, $19^{\text {th }}$ of July, 2020

\author{
Charles Edquist ${ }^{\mathrm{t}^{*}}$, Jon Mikel Zabala-Iturriagagoitia ${ }^{\mathrm{b}}$ \\ a.- CIRCLE, Lund University, Lund, Sweden. ORCID ID: 0000-0003-1010-237X. \\ b.- Deusto Business School, University of Deusto, Donostia-San Sebastian, Spain. ORCID \\ ID: 0000-0003-1975-2555.
}

\begin{abstract}
$\underline{\text { Abstract }}$
Public procurement accounts for a very large share of most economies worldwide. It represents more than $15 \%$ of global GDP, which is many times larger than the world expenditures on research and development. Besides its direct purchasing power, public procurement has an enormous potential to become one of the most important mission-oriented policy instruments in the context of the Sustainable Development Goals.

This conceptual paper argues that the key to achieving more innovations when pursuing public procurement is to describe problems to be solved or functions to be fulfilled (functional procurement) instead of describing the products to be bought (product procurement). We contend that if products can be described in the procurement documents, it is because they exist, and hence, they cannot be regarded as innovations. Innovations cannot be described ex ante simply because they do not exist. It is therefore not accurate to talk about 'innovation procurement'. Accordingly, the only way to achieve an innovation by means of procurement is by describing the functions it is to fulfill or the problems it is to solve. For public procurement to become an effective policy instrument supporting innovation, product procurement should thus be transformed into functional procurement.

Contracting authorities need to identify the problems that policy should address. The new products (innovations) solving the problems are to be designed by the potential innovators/suppliers, not by public procurers. Hence, the societal needs and problems must be translated and transformed into functional requirements.

Functional procurement is allowed in EU regulations, and therefore, there are no legal obstacles to using it for innovation policy purposes. Above and beyond, the European directives recommend using functional requirements "as widely as possible". Furthermore, it leads to increased competition, not only among potential suppliers of similar products, but also among different products that solve the same problem. Functional procurement thus not only supports innovation but also serves as a powerful competition policy instrument.
\end{abstract}

Keywords: innovation policy, public procurement, product procurement, functional procurement, functional requirements, competition policy. 


\section{Highlights}

- The resources used for public procurement are much larger than the world expenditures on $\mathrm{R} \& \mathrm{D}$.

- To enhance innovation through public procurement, functional requirements should be used.

- Functional public procurement is a transformative policy instrument (i.e. a game changer).

- It is not possible to describe not-yet-existing products in advance.

- It is therefore not accurate to talk about 'innovation procurement'.

- There are no legal obstacles to using functional procurement in the EU regulations.

- Functional procurement not only supports innovation but also enhances competition. 


\section{Index}

Charles Edquist, Jon Mikel Zabala-Iturriagagoitia................................................................... 2

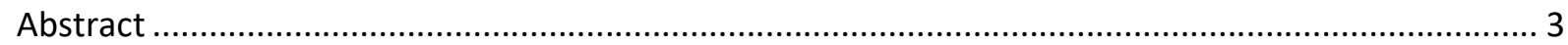

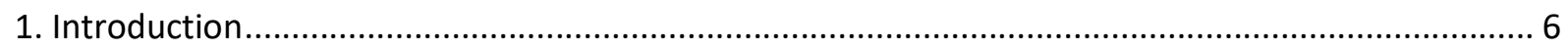

2. Basic concepts - and some remarks on their emergence ............................................................ 7

3. Which kinds of public procurement promote innovation? ............................................................ 11

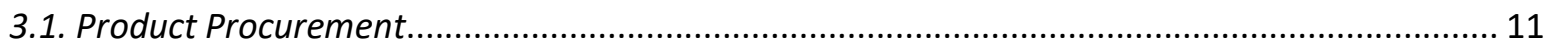

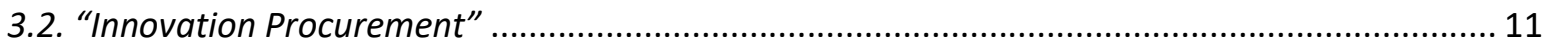

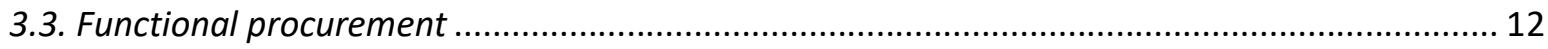

4. Is functional procurement allowed? Yes, it is strongly encouraged! .............................................. 14

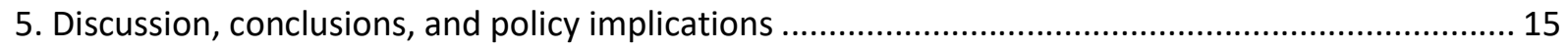

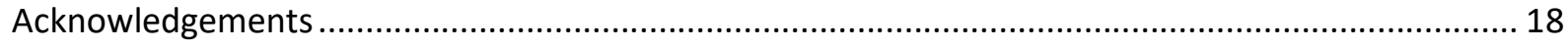

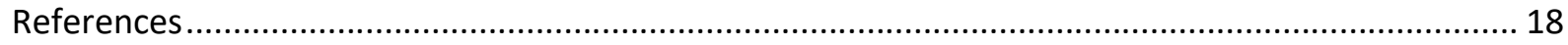




\section{Introduction}

Grand challenge mitigation is framing many innovation policies and strategies worldwide (Mazzucato, 2018). Edquist and Zabala-Iturriagagoitia (2012) introduced public procurement as a relevant and potentially powerful "mission-oriented policy" instrument aiding in grand societal challenge mitigation. According to the results of the ERAC consultation (European Union, 2015), the estimations of public procurement expenditures on works, goods and services were close to $€ 2.3$ trillion per year in the EU, equaling 19.4\% of European GDP (see also Kahlenborn et al., 2010). ${ }^{1}$ Public procurement spending is thus many times larger than the world expenditures on research and development (R\&D).

However, the share of the whole procurement spending used to stimulate innovation remains insignificant, although no comprehensive statistics on this exist to date (Edquist, 2017). Innovation-related procurement is now acknowledged as a relevant policy instrument, particularly as a mission-oriented innovation policy instrument related to grand challenge mitigation. Despite this general context, in terms of its implementation and the mechanisms for its effective rolling out, it is still in its infancy (Uyarra et al., 2020). This is linked with the discussions that are increasingly taking place in the academic realm as to the need to address the "implementation" of innovation policies (see Howlett, 2019).

The purpose of this paper is to analyze how public procurement can enable and act as a driving force for innovations, which in turn can increase welfare as well as improve the environment. Hence, the paper focuses on public procurement that requires or facilitates innovations. Consequently, we will not deal with product procurement ${ }^{2}$, namely the kind of public procurement where one describes and buys existing and well-known products (which are obviously not innovations). Notwithstanding, product procurement constitutes the largest volume of all procurement spending.

In this paper we will only address public procurement for which the EU procurement directives are applicable, i.e. works, goods or services (Directive 2014/24/EU of 26 February 2014). ${ }^{3}$ There are other kinds of public procurement (e.g. Pre-Commercial Procurement (PCP)), which are related to the public procurement of research results (see Edquist and Zabala-Iturriagagoitia, 2015). We will not deal with this form of public procurement in this paper, since it is based on an exemption from EU procurement directives. Neither will we discuss the procurement of what is unclearly called "innovative solutions".

From our point of view, it is important to distinguish between procurement that leads or can lead to innovations and procurement that does not lead to innovations, or even prevents them. We will argue that the most important way of achieving more innovations when pursuing public procurement is to conduct functional procurement (i.e. formulate functional requirements in the procurement documentation). https://translate.googleusercontent.com/translate $f$ - ftn2An important and related issue to be discussed is also how product procurement can be converted into functional procurement in order to enhance innovations.

Innovations (new products or new processes) can lead to the creation of societal and environmental problems, but they also have the potential to solve problems and mitigate global challenges in these same categories. They can both destroy and create jobs or lead to

\footnotetext{
${ }^{1}$ According to the data provided by the Tenders Electronics Daily $€ 420$ bn is procured per year in the EU: https://ted.europa.eu/TED/main/HomePage.do.

2 Product procurement encompasses the purchasing of both goods and services, and is sometimes called traditional or regular procurement. The product to be procured is described in the procurement documents.

${ }^{3}$ Directive 2014/25/EU of 26 February 2014 deals with "procurement by entities operating in the water, energy, transport and postal services sectors".
} 
dirty as well as green GDP growth. Innovations can increase productivity through a more efficient use of resources and contribute to increased competition, not only between different suppliers of similar products, but also between radically different products designed to solve the same problem.

Whether the effects of innovations become negative or positive depends on the goals ${ }^{4}$ set for public procurement, for innovation development and for innovation policy, and whether or not these are met. This relates to the discussion on the role that innovation plays in economic and societal transformation and transformative innovation policy (Schot and Steinmueller, 2018; Fagerberg, 2018). This discussion, however, is beyond the purposes of this paper, and scholars like Strumsky et al. (2010), Fragkandreas (2013) and Crafts (2018) have examined it at length.

The remainder of the paper is structured as follows. Section 2 specifies the basic concepts used and their emergence. In Section 3 we will discuss the differences between product procurement, 'innovation procurement' and functional procurement and how these phenomena relate to each other. We will also address the question of which kinds of procurement enhance innovation. Section 4 shows that functional procurement is allowed, and even encouraged by EU regulations if the purpose is to enhance innovations. It also discusses how product procurement can be transformed into functional procurement, so that public procurement can become a demand-side policy instrument that effectively promotes innovation. Section 5 discusses conclusions and policy implications and provides a summary of the paper.

\section{$\underline{\text { 2. Basic concepts - and some remarks on their emergence }}$}

In order to move forward, it is worth clarifying what is meant by "innovations", "public procurement" and "procurement documents", which are at the core of public procurement processes. Following the latest revision of the Oslo Manual, innovations are defined as new creations of economic or societal significance, which are usually implemented by companies. ${ }^{5}$ Innovations can be new or improved products or processes. New products (i.e. product innovations, which provide new qualities) may be tangible goods or non-material (i.e. intangible) services; it is a matter of what is produced. ${ }^{6}$ New processes (i.e. process innovations) can be technological or organizational, it is a matter of how the products are created, provided or manufactured, and they may include artifacts used in the production (i.e. manufacturing) of goods and services, the use of ICT systems, activities related to marketing and sales, or those in administration and management (see OECD/Eurostat, 2018: 75). ${ }^{7}$ In all cases, it is extremely important to note that these new creations do not become innovations until they have been substantially commercialized or otherwise disseminated to a significant

\footnotetext{
${ }^{4}$ The goals of innovation policy are politically determined. For a discussion, see Edquist (2014, 2017, 2019a) and Borrás and Edquist (2019).

${ }^{5}$ This definition of innovation is based on the Oslo Manual (OECD/Eurostat, 2018: 20), according to which "a new or improved product or process (or combination thereof) that differs significantly from the unit's previous products or processes and that has been made available to potential users (product) or brought into use by the unit (process)".

${ }^{6}$ It is a common misconception that products are the same as material goods. However, it is important to emphasize that products also include intangible services.

7 Process innovations have been product innovations in a previous 'incarnation' (Abernathy and Utterback, 1978). For example, an industrial robot is first sold as a product innovation and then used as a process innovation by the buyer. This is an explanation of why we are mainly referring to new products here rather than new processes as a possible result of public procurement.
} 
extent in society. Developing a prototype or a test series is not enough for something new (a new creation) to qualify as an innovation (Edquist and Zabala-Iturriagagoitia, 2015).

Public procurement has to do with demand and occurs when a contracting public organization (i.e. authority, entity), which can be national, regional, local or international, buys a product (i.e. a good or a service, or a combination of such as a system). It must also be included in the contract that a certain number of units of the product (i.e. good, service, or a combination of both) are to be delivered and will be paid by the contracting authority.

As the European Directive 2014/24/EU of 26 February 2014 on public procurement states, a procurement document "means any document produced or referred to by the contracting authority to describe or determine elements of the procurement or the procedure" (European Union, 2014: L 94/97). Besides, the procurement documents should include "the contract notice, the prior information notice where it is used as a means of calling for competition, the technical specifications, the descriptive document, proposed conditions of contract, formats for the presentation of documents by candidates and tenderers, information on generally applicable obligations and any additional documents" (ibid). The information provided in the procurement documents must be sufficient for a supplier to be able to assess the nature and scope of the procurement, and thus be able to decide whether to apply for participation in the procedure (ibid: L 94/111).

In most procurement documents there are different types of requirements that may, for example, be related to information security, delivery aspects, etc. The most important part of the majority of all procurements is based on documents that also contain a description of an existing product that the public organization concerned wants to buy. Often this description is quite - or even very - detailed (see Edquist et al., 2000 for some examples). When such a product description is included, the term "product procurement" is used in this paper.

There may also be requirements in terms of functions (Martin, 2002; Edler and Georghiou, 2007; Georghiou et al., 2014). Hence, functional requirements represent an alternative to product descriptions. ${ }^{8}$ In this regard, despite some case studies being found both in theory and in practice (e.g. Suchman and Eyre, 1992; Suman, 2006; Johansson and Lahtinen, 2013; Georghiou et al., 2014; Aldenius and Khan, 2017), it is relatively uncommon to roll out public procurement in a systematic way through the definition of functional requirements (Edquist et al., 2018). If functional requirements are used, the procurement documents often include a mixture of product descriptions and functional descriptions (Ang et al., 2005). However, there are no systematic statistics on how this looks in detail to date. One must study individual procurement documents to obtain such data. It is important that such investigations are conducted. Only in that way will we be able to move beyond case studies and deliver a systematic view of public procurement as a policy instrument with an effective impact on innovation.

If an existing product is described in a detailed manner in the procurement documentation (i.e. product procurement), potential suppliers will then try to provide exactly such a product. You simply get the products you describe, even if these may be obsolete, meaning that a better alternative which the public procurer is not aware of may already exist in the marketplace. Of course, such product specification will not result in new products (i.e. innovations). And when evaluating such product procurements, price will be the dominant criterion when deciding from whom to buy (Bergman and Lundberg, 2013).

\footnotetext{
${ }^{8}$ In the literature, functional requirements are often also labeled as performance requirements (Martin, 2002) or functional standards (Suman, 2006).
} 
For many decades, researchers, policy-makers and procurers have used, and still use, such terms as innovation procurement, innovative procurement, public procurement of innovation, and the like (see Obwegeser and Müller, 2018). For example, in Sweden the term innovation procurement is used by the National Procurement Agency and VINNOVA (i.e. the Swedish national innovation agency). Many other public agencies worldwide also use similar labels to refer to this type of innovation-related procurement. The reason is probably that they have been interested in creating innovations as a result of public procurement in order to mitigate the socioeconomic challenges faced by municipalities and regional and national state authorities.

Like other scholars, in previous studies we have also argued that innovations can be achieved through public procurement by describing products that do not exist (Edquist et al. 2000, 2015; Edquist and Zabala-Iturriagagoitia, 2012, 2015), and which would therefore become innovations if they were developed. Further reflections have, however, led us to conclude that this is indeed impossible, and that the term innovation procurement, as well as the previous similar concepts, is therefore inappropriate. ${ }^{9}$ If products can be described in the procurement documents, it is because they exist, and hence, they cannot be regarded as innovations. Innovations cannot be described ex ante. One cannot describe not-yet-existing products in advance. In this respect, we would like to refer to the philosopher Karl Popper, who pointed out that we cannot predict future knowledge (1957). Anyone who claims to be able to correctly describe and predict certain future knowledge actually claims to already have this knowledge - although it does not exist. This is a contradiction. ${ }^{10}$ What applies to knowledge in a general sense also applies to innovations.

Of course, the procuring entity wants to buy products in order to use them for some particular purpose. In other words, with the help of the product, public organizations usually want to achieve a goal or a mission, solve a societal problem, satisfy human needs, be able to address and hence meet (global) challenges, or have a function fulfilled. And this is done in the interest of citizens. An alternative to product procurement is that the procuring organization describes these problems, missions or functions in the procurement documents. When such a description exists, we use the term "functional procurement". Functional procurement is when a public agency buys products that perform functions that provide solutions to problems.

In the case of functional procurement, the procuring organization specifies what is to be achieved rather than how (i.e. with the aid of which product, method, technology, language processing, programming code, etc. it should be done). ${ }^{11}$ Functional procurement can lead to new products (innovations) developed in the procurement process, and hence, it opens for innovation (Edler and Georghiou, 2007; Georghiou et al., 2014). However, functional procurement does not necessarily require the development of innovations. A new product that did not exist at the outset of the procurement could be the result. Naturally, existing products

\footnotetext{
${ }^{9}$ An interesting point in this context is that the term "innovation procurement" does not appear at all in the Swedish Procurement Act, which follows the EU procurement regulations and is therefore similar to procurement laws in all EU Member States. Directive 2014/24/EU on public procurement only uses the term "innovation procurement" to indicate that "the important differences between individual sectors and markets, it would however not be appropriate to set general mandatory requirements for environmental, social and innovation procurement" (Recital 95) and that "In order to fully exploit the potential of public procurement to achieve the objectives of the Europe 2020 strategy for smart, sustainable and inclusive growth, environmental, social and innovation procurement will also have to play its part" (Recital 123).

${ }^{10}$ Popper's real interest was to prove that "for strictly logical reasons it is impossible for us to predict the course of history" (1957: ix).

${ }^{11}$ In words of Edler and Georghiou (2007: 960) "for the tender process to induce innovation in the market place, it is indispensable that it is based on specifying functionalities rather than designs".
} 
could also outcompete the newly developed innovations, and finally be selected by the public procurer if they more fully satisfy the purpose of the procurement. Thus, the product as such is not the goal of the procurement, but rather a means to achieve the goals intended with it, whether they involve solving societal problems, satisfying human needs, or meeting (global) challenges (Diercks et al., 2019; van den Hove et al., 2012). Obviously, this does not imply that all problems/needs can be solved/satisfied through public procurement. Of course, many social problems require social and political solutions instead (e.g. gender equality, social justice).

The above arguments have led us to the conclusion that, from an innovation perspective, there are reasons to talk about - that is, to construct or create - two main types of public procurement: ${ }^{12}$

1. Procurement based on product specifications (product procurement) is when a public organization describes the products that it wants to buy.

2. Procurement based on functional specifications (functional procurement) is when a public organization describes problems/functions/needs that must be solved/fulfilled/met through the procurement and use of products.

The difference between these two types of public procurement is thus the way in which the procurement is advertised (i.e. how the procurement documents are formulated) and how the procurement process is carried out. These two main categories are both simple, effective, and sufficient to pursue a procurement policy that leads to innovations. This is done by transforming product procurement into functional procurement, or at least by increasing the proportion of functional procurement in the total procurement (see Edquist, 2017). ${ }^{13}$

Different procurement taxonomies have been developed in the literature to classify public procurement into its different forms (e.g. Edquist et al., 2000, 2015; Edler and Georghiou, 2007; Hommen and Rolfstam, 2009; Uyarra and Flanagan, 2010; Rolfstam, 2013; Timmermans and Zabala-Iturriagagoitia, 2013; Georghiou et al., 2014; Knuttsson and Thomasson, 2014; Lember et al., 2014; Edquist and Zabala-Iturriagagoitia, 2012, 2015; Edquist, 2019b; Uyarra et al., 2020). The development of this new and very simple, but purposeful typology means that we have fundamentally changed our view of the categories and concepts needed to understand and explain the relationships between public procurement and innovation. It has also radically changed our perspective of how one should conduct policy and practical procurement activities in the area.

Obviously, product procurement and functional procurement are 'ideal' types. The relation between the two may sometimes be complex and multifaceted. An important question is whether our typology instead could be seen as a continuum from product, to mixed, to pure functional procurement instead?

While it is true that in many cases only one of them (product, functional) is present in the documents for a specific procurement initiative, they may also co-exist in one and the same procurement. Conceptualizing these two ideal types of public procurement is however important, for us to be able to distinguish between the implications of each of these two categories for analytical and for innovation policy design reasons. One of the reasons for this is that while one of them prevents innovations, the other opens for them. If only one of the two ideal types is present, the effects on innovation mentioned above will materialize. If both of them are present in the documents, it is reasonable to assume that they are inconsistent and that the product specifications become dominant - and this is then an obstacle to innovation.

\footnotetext{
${ }^{12}$ Czarnitzki et al. (2018) also differentiate between innovative and regular procurement contracts.

${ }^{13}$ See Section 3.
} 
The conclusion will then be that it is not a good idea to add a functional specification without removing the product specification. However, this issue must be analyzed further, preferably empirically. To our knowledge there exists no such study to date. Our preliminary conclusion on this point is that product and functional specifications should be dealt with separately. At the micro level of particular procurements, the relation between the two categories cannot be seen as a continuum. At meso and macro levels, it is useful to talk about the proportion of each of the two categories of procurement as well as those that contain both.

\section{Which kinds of public procurement promote innovation?}

In this section we will discuss in greater detail what we mean by product procurement, 'innovation procurement' and functional procurement and how these phenomena relate to each other and to innovation processes.

\subsection{Product Procurement}

In product procurement, the contracting authority buys existing products (i.e. "off the shelf", as we have contended in other contributions), and hence, it does not require any innovations from tenderers and potential suppliers. Merely describing previously procured products makes it difficult, or impossible, for new products (innovations) to be accepted.

As argued in Section 1, the contracting authority simply gets what is described in the procurement documents. ${ }^{14}$ And if they can be described by the procuring organization, they are not innovations, but existing products. You get what you order, even if it is an obsolete product. As a result, qualitatively superior products will be excluded in the procurement process, as argued in Section 2. Innovations will thus not result from product procurement, except in exceptional cases.

\section{2. "Innovation Procurement"}

During the last decades of the 20th century, some of us began to argue that public procurement should increasingly lead to technological development and ultimately to innovation (Edquist et al., 2000). ${ }^{15}$ This was due to the fact that technological change is an extremely important factor for the development of the economy and society, and because innovation and public procurement account for such a large part of the economy (see Section 1). It was therefore natural to talk about 'innovation procurement'. The basic rationale behind this idea was that a new product (i.e. an innovation) was the goal and hence, it should be the result of the so-called "innovation procurement" (Chicot and Matt, 2018). Innovation procurement and public procurement for innovation (PPI) have thus been concepts often used to refer to situations when demand from public organizations is used to enhance innovation.

Our later reflections have, however, led us to conclude that innovation procurement should mean when a public organization places an order for the fulfillment of certain functions within a reasonable period of time, by delivering a new product (product, service or system) that does not exist at the time of the order, rather than product procurement. Innovation procurement should hence focus on functions that satisfy human needs or solve social problems, and not on stimulating the development of new products per se (Edquist, 2014: 15).

As discussed earlier, the product is only the means to achieve the function $/ \mathrm{need} / \mathrm{mission}$. Procurement leading to innovations thus requires a functional description. If the functional

\footnotetext{
${ }^{14}$ Of course, contracting authorities do not always aim to promote innovation in their public procurements. Product procurement can thus be used when purchasing, for example, staple goods such as toilet paper.

15 Terms used at that time were "technological development" and "technical change". Later we started to talk about "innovations" in a more general sense, which we defined in Section 2.
} 
descriptions exclude existing products, the procurement leads to an innovation, or it may also lead to a failure if no innovations result from the procurement process. In turn, if the functional descriptions allow for the inclusion of already existing products, either the existing or the new products can be procured.

In one part of the European Commission (DG CONNECT), PPI and PCP are emphasized as relevant instruments supporting innovation within the H2020 programme. "Innovation procurement" is also highlighted by the OECD (OECD, 2016). PPI and PCP are used to fund "innovation procurements" in fields such as health, security, energy, transport, satellite and research infrastructures. For example, in 2016, PCP and PPI actions managed by DG CONNECT amounted to around $€ 40 \mathrm{M}$, in 2017 to $€ 84 \mathrm{M}$. In turn, the budget for innovation procurements (PCP+PPI) in the 2018-2020 Horizon 2020 programme was expected to surpass the $€ 212 \mathrm{M}$ (i.e. $€ 53.7 \mathrm{M}$ in $2018, € 69.5 \mathrm{M}$ in 2019 , and $€ 89.5 \mathrm{M}$ in 2020 ). In this paper we have argued that it is not accurate to use the term "innovation procurement".

According to DG CONNECT, PCP "addresses the development and testing of innovative solutions", while PPI "focuses on the deployment of innovative solutions". ${ }^{16}$ As we shall see in Section 5, functional procurement is strongly emphasized in another part of the European Commission, i.e. in DG GROW, where the regulations (the legislative framework) for public procurement are formulated. It is surprising to observe this lack of conceptual clarity and this conceptual inconsistency between different parts of the same organization, particularly when it is an organization with so much policy influence as the European Commission. The Commission talks with two different voices (i.e. one supporting "innovation procurement" and the other encouraging functional procurement).

\subsection{Functional procurement}

As already defined, functional procurement is when a public agency buys products that perform functions that provide solutions to problems. ${ }^{17}$ Hence, this form of public procurement should not describe the product demanded (product specification), but rather describe the problem or need (functional specification) to be solved/satisfied.

In functional procurement, a public agency specifies what is to be achieved rather than how it is to be achieved. A functional tender thus requires a process by which the need or problem is accurately identified, translated into functions, and presented as requirements in terms that potential suppliers can respond to in the formal tender. This implies a change in the behavior of public contractors so they become more focused on the needs to be addressed rather than on the potential solutions that may solve them (Martin, 2002; Georghiou et al., 2014).

One of the roles of innovation policy is to create conditions and incentives for the systematic emergence and development of innovations that help address socioeconomic and environmental needs (Metcalfe, 1995; Palmberg, 2006). In order to achieve innovation through public procurement it is, somewhat paradoxically, more important to emphasize functional specifications than to try to pursue "innovation procurement", since functional specifications open for innovations in all types of public procurements.

In line with the discussion in Section 2, we argue that the category functional procurement can, in turn, be further divided into two subgroups:

A. Functional procurement where the functional specification includes existing products.

\footnotetext{
16 See: $\quad$ https://ec.europa.eu/digital-single-market/en/news/1185m-euros-new-eu-funding-innovationprocurements. "Innovative solutions" is a much vaguer concept than "innovations" as defined in Section 2 above. It also needs to be noted that the term "Innovative solutions" is not used at all in the Oslo manual.

${ }^{17}$ The perspective on functional procurement has been developed in Edquist $(2014,2015,2017,2019 \mathrm{~b})$ and Edquist et al. (2018).
} 
B. Functional procurement where the functional specification does not include existing products.

The difference between $\mathrm{A}$ and $\mathrm{B}$ lies in how broad or comprehensive the functional specifications are. The functional specifications used in Type A can, of course, result in the continued procurement of existing products if no better or cheaper products (innovations) are developed and offered. However, it does not exclude the development of innovations since functional specifications are based on a problem to be solved or a need to be satisfied. If the new products perform the functions required to solve the problems described better than the old product, then they should be chosen by the public procurer. This implies that type A functional procurement requires comparing the different solutions to the same problem when evaluating tenders (Edler et al., 2005; Tysseland, 2008).

Type B specifications are based on functional specifications that require a new and better product to be developed to fulfill the function or solve the problem before delivery can take place. An alternative, however, is that the procurement completely fails because no new product that meets the specification is developed. The exclusion of existing products in the functional description (type B) may be because there are no such products at all, as the procurement has been oriented towards fulfilling a need or solving a problem which had not been addressed before. Another reason for excluding existing products may be that more advanced products than those currently available in the marketplace are absolutely necessary, due to the negative impact of old products, for example, on the environment. For example, you can exclude old refrigerators by requiring in the functional description that energy consumption should be half that of existing products and that no freon should be used due to its negative environmental impact. This is what the Swedish Energy Authority did in the late 1980s (see Edquist et al., 2000; Neij, 2001). A more recent example of the implementation of functional procurement, amongst others, can for example be found in the Netherlands, where the Directorate-General for Public Works and Water Management (i.e. Rijkswaterstaat) defined a call to reduce the noise along secondary roads, which received various potential innovative solutions. ${ }^{18}$

Functional descriptions can also be narrow or broad in other respects than excluding/including existing products. In this sense, the regulations impose certain requirements: "The design of the procurement shall not be made with the intention of excluding it from the scope of this Directive or of artificially narrowing competition. Competition shall be considered to be artificially narrowed where the design of the procurement is made with the intention of unduly favouring or disadvantaging certain economic operators" (European Union, 2014: L 94/106). The type of specifications used in the call "shall not refer to a specific make or source, or a particular process which characterises the products or services provided by a specific economic operator, or to trademarks, patents, types or a specific origin or production with the effect of favouring or eliminating certain undertakings or certain products. Such reference shall be permitted on an exceptional basis, where a sufficiently precise and intelligible description of the subject-matter of the contract... is not possible. Such reference shall be accompanied by the words 'or equivalent'” (ibid: L 94/121).

\footnotetext{
${ }^{18}$ Further examples of functional requirements can be found in the Guidance on Innovation Procurement edited by the European Commission (2018). In Sweden, the Swedish Procurement Agency also provides different examples of how functional demands can be used in public procurement (see http://www.upphandlingsmyndiheten.se). In addition, a plan of action for implementing functional procurement is being developed in Sweden (see section 5.6 in Edquist, 2019b - in Swedish).
} 
Hence, product specifications must not be formulated in such a way that competition is hampered. The best way to possibly avoid this is to use functional specifications, as a function can often be fulfilled by several different alternatives. We return to this question in Section 5 .

If a very narrow functional description is used, "unexpected" innovations that come from unpredicted directions or new areas of research would be excluded. Contracting authorities cannot predict from where innovations may emerge. Neither can they define what the innovations may look like or what characteristics they may have. Therefore, working with broad and generic functional descriptions should be encouraged. However, they cannot be too general either. Further analyses are required to arrive at some kind of optimal "breadth" of functional descriptions.

\section{Is functional procurement allowed? Yes, it is strongly encouraged!}

The EU directives on public procurement are very important for all procurement in the European Union. In this regard, the Directive 2014/24/EU of 26 February 2014 states:

"The technical specifications drawn up by public purchasers need to allow public procurement to be open to competition as well as to achieve objectives of sustainability. To that end, it should be possible to submit tenders that reflect the diversity of technical solutions standards and technical specifications in the market place, including those drawn up on the basis of performance criteria linked to the life cycle and the sustainability of the production process of the works, supplies and services. Consequently, technical specifications should be drafted in such a way as to avoid artificially narrowing down competition through requirements that favour a specific economic operator by mirroring key characteristics of the supplies, services or works habitually offered by the economic operator. Drawing up the technical specifications in terms of functional and performance requirements generally allows that objective to be achieved in the best way possible. Functional and performance-related requirements are also appropriate means to favour innovation in public procurement and should be used as widely as possible" (European Union 2014: Recital 74 - extra bold type added by the authors). ${ }^{19}$

It is interesting that the EU Directives highlight functional requirements, and remarkable that they emphasize that they "should be used as widely as possible" to favor innovation in public procurement. Since functional requirements are included in the legislation, there are no legal obstacles, and functional demands can always be used in the tender specifications, without changing any laws or rules. However, in practice, functional requirements are still not used to a large extent and in a systematic way in public procurement tenders. ${ }^{20}$

The emphasis on functional specifications in the EU public procurement rules is not only intended to promote innovation. It may also serve as a powerful competition policy tool. The mechanism is that functional descriptions lead to increased competition between different

\footnotetext{
19 A performance requirement is the same as a functional requirement. This means that the procurement documents can specify a certain energy reduction compared to the best available technology, without specifying how this reduction will be achieved.

${ }^{20}$ In the Swedish National Procurement Strategy, adopted by the Swedish Government in 2016, functional procurement is given an important role as an instrument that may enhance innovation. The development, adoption and implementation of the Swedish National Procurement Strategy is described and analyzed in detail in Edquist (2019a, 2019b) and in Borrás and Edquist (2019).
} 
products to satisfy the same needs or solve the same problem. Not only does it increase competition between different companies offering similar products. It also increases competition between different (companies offering different) products that can fulfill the same function (Anderson and Kovacic, 2009).

The technical requirements should thus not reflect important characteristics of the goods and services that a supplier usually offers or describe requirements too precisely. This goal is met in the best possible way if the technical specifications are designed as functional and performance requirements. As argued in Section 3, for competition reasons, it is best, according to our interpretation, that goods and services (i.e. product procurement) are not described. Rather, the functions that they are intended to perform should be described.

Functional procurement is not included as one of the "procurement procedures" in the EU regulatory framework for public procurement, which has to be followed by all EU Member States. ${ }^{21}$ Functional procurement represents a way to use any of the specified procurement procedures. Under current regulations, one of the procurement procedures must always be used when functional requirements - or other requirements - are specified. This is a legal fact and cannot be changed in the short term. Summing up, functional procurement is allowed, and it is even strongly encouraged by the EU regulations - both for innovation and competition reasons.

\section{Discussion, conclusions, and policy implications}

Public procurement accounts for a large share of most economies worldwide. Besides constituting direct purchasing power, public procurement is also increasingly used as a tool to achieve additional policy objectives, such as environmental, economic, and societal goals (McCrudden, 2004; OECD, 2017). Public procurement is a transformative instrument (i.e. a game changer) because it can help to create the conditions for creativity, and for the development, diffusion and uptake of innovations, which is ultimately the purpose of innovation policy (Borrás and Edquist, 2013, 2019; Mastroeni et al., 2013).

However, most public procurement is not innovation related. Scholarly work has long discussed how the procurement of existing goods and services can partly be transformed to explicitly demanding non-existing products, in what has been termed innovation procurement'. The products procured usually constitute a means to solving a problem or fulfilling a function. And this is (mostly) done in the interest of citizens.

In this paper we have argued that it is not accurate to talk about 'innovation procurement' in the sense that non-existing products are described and demanded. It is simply not possible to describe ex ante something that does not exist. Many regular public procurements are perfunctorily conducted; the procuring agency or unit describes the same product as in previous procurements in a routine manner. These products must obviously be existing ones since they can be described by the contracting authorities. If that is the case, qualitatively superior products (i.e. innovations) may be excluded from the procurement process. A routine of simply describing the previously procured products in tender documents makes it difficult or impossible for new products (innovations) to be accepted. It is a serious obstacle to innovation. You simply get the products you describe. And if they can be described, they are not innovations.

21 These procedures are: open procedure, restricted procedure, competitive procedure with negotiation, negotiated procedure with prior advertising, negotiated procedure without prior advertising, competitive dialogue, or innovation partnerships (see European Union, 2014 - Title II - Chapter 1). 
In this paper we have labeled this kind of procurement "product procurement". An alternative to product procurement is that the procuring organization should describe, in the procurement documents, the problems, needs and functions that they are interested in. When such a problem description exists, we use the term "functional procurement". Our definition is: Functional procurement is when a public agency buys products that perform functions that provide solutions to problems. When it comes to innovation, the biggest difference between these two categories is that while product procurement can only rarely lead to innovations being developed, functional procurement opens virtually all procurements to the development of new and better products. We have argued that our proposed distinction between product procurement and functional procurement is a conceptual distinction that provides a new basis for the discussion and policy practice of the relation between innovation and public procurement. Functional procurement and product procurement are thus alternatives and not supplements to each other. The conclusion for innovation policy is that the proportion of functional procurements should increase and the part that is product procurements should decrease, if innovation shall be enhanced through public procurement.

In turn, the category functional procurement can be further divided into two subgroups (see Section 3):

A. Functional procurement where the functional specification includes existing products.

B. Functional procurement where the functional specification does not include existing products.

An important argument for including existing products in the functional specifications is that the risk of failure of the procurement is almost non-existent. If no new products are developed in the procurement process, or if the new products do not outperform the existing ones, then the pre-existing product can always be purchased. It is obvious that it is simpler and less risky to do product procurement than functional procurement - at least initially. This is true for both public organizations and the individuals employed in these. Such risk aversion decreases the propensity to carry out functional procurement. One consequence of this risk averse behavior is that it can lead to lack of renewal and to lower quality of the services offered by the procuring organizations.

To stimulate managers and employees of contracting authorities to take larger risks, they have to be "protected" by elected politicians (see Edquist et al., 2015: 15). The enormous volume of public procurement is an argument here. It means that a limited volume of risky projects can be assumed within contracting authorities (i.e. the risks can be spread in the portfolio as a whole). On the other hand, media often attacks policy failures and criticizes individual politicians for this, rather than accepting them as a part of a large volume. This may be reflected in election results. Hence, considerable skills are needed to keep the attention on the results achieved through the procurement activity as a whole, and not by the risky part of it. This certainly looks like a case of "catch 22" (see Borrás and Edquist, 2019: 121). Despite this, we consider it is necessary that elected politicians absorb these risks to keep the risk aversion low enough to prevent it from being a too large obstacle for rolling out functional procurement. Assuming these organizational and political risks may thus be needed (Digss and Roman, 2012), since the ultimate goal of procurement policy is to increase the effectiveness and efficiency of the public sector, and to solve/address problems/needs for which innovations are required.

In a choice between functional descriptions of type A and type B (see Section 3), type A may be more effective. A pre-existing product can still be procured, as long as it fulfills the functional specifications. Therefore, functional procurement does not (necessarily) mean that an innovation results from the procurement. Including old products in the specification 
reduces the risk, but still opens for innovations. In addition, there are strong arguments for broadening the specifications so as not to exclude unexpected innovations. A reason for this is that contracting authorities cannot predict where innovations may emerge. Therefore, working with broad and generic functional descriptions should be encouraged. However, there are, of course, limits to this scope. Where these boundaries are must be further analyzed.

In this paper we have argued that functional procurement is, from an innovation and needs satisfaction point of view, advantageous for all public procurement. This is simply because product specification acts as an obstacle and usually makes it impossible for innovations to be the result of procurement processes. Naturally, functional procurement can be combined with other innovation policy instruments. Functional specifications can also be combined with Precommercial Procurement (PCP). PCP is a matter of buying research results that solve certain problems, not procurement of new products. These research results - just like innovations are not known ex ante and cannot be described at the outset of the procurement process. This implies that PCP should normally be a matter of functional specifications (of research results).

The most important task in preparing for functional procurements is to identify the problems and needs to be solved/satisfied. It is a question of specifying the goals (problems and needs) in a simple and overarching way. Identified societal needs and problems must be translated and transformed into functional requirements (Koivisto, 2018). Solutions to problems are to be designed by the potential innovators/suppliers, not by public procurers. Contracting authorities should only specify problems and functions. If not, the creativity and innovativeness of potential suppliers will be hampered. It may also lead to development being locked into wasteful and ineffective paths. By the same token, too detailed functional specifications may also be an encumbrance for innovation (Uyarra et al., 2014).

Knowing what procuring organizations or contracting authorities want/need is not a trivial task. It requires time and cooperation between departments, which can be a barrier. Sometimes the supplier may not understand the need properly, which in turn leads to a contract not fulfilling the need. In this regard, overly detailed specifications can increase rather than decrease risk of not fulfilling the demands. Thinking in terms of what is needed rather than how the need is met requires a change in mind-set in the specification, selection and contract monitoring stages. Developing the required capabilities to identify needs and problems is thus central for the further development of the ability of contracting authorities to make public procurement work effectively (Kattel and Mazzucato, 2018).

Functional procurement also provides directionality to innovation policy-making (Edler and Boon, 2018). As Mazzucato (2018: 805) argues, innovation policy should not choose what to promote, but rather, how to promote: "picking directions is... about deciding that a transformation must occur in society and making it happen". While the global sustainable development goals can set the ambition of mitigating problems, we believe that functional procurement can contribute substantially to solving these problems.

Both the speed of innovation processes and their direction are affected if functional descriptions instead of product descriptions are used in public procurement. The direction of innovations processes is influenced by specifying functions, for example that solutions to environmental problems are required. This means that functional procurement can help mitigate global challenges, for example in the climate field. It is a matter of the objectives of innovation policy. Once the direction of innovation processes has been established, the speed at which they move can also be affected by the fact that product descriptions do not hinder the speed of innovations.

Finally, functional procurement also helps release enormous creativity and innovativeness among suppliers, and ultimately for the public sector and society as a whole. In turn, it also 
leads to increased competition, not only among potential suppliers of similar products, but also among different products that solve the same problem. Functional procurement favors competition as well as innovation. And maybe, the best way to increase competition is innovation policy!

\section{Acknowledgements}

This paper is partly based on a report written by Charles Edquist at the request of, and published by, the Swedish Competition Agency (Konkurrensverket) (Edquist 2019b). A preliminary version of this paper was presented at the EU-SPRI 2019 conference held in Rome (Italy), 5-7 June, 2019. However, the paper has both been shortened and also developed and improved in many respects. Jon Mikel Zabala-Iturriagagoitia made considerable contributions to this development and the two authors have contributed equally to the paper published now. Several individuals provided comments to the report for the Competition Agency. These include Niklas Tideklev, Louise Strand, Anette Jonsäll, Sigrid Petersén, Ingvar Johansson, Mattias Berger, Lars Bengtsson and Joakim Wallenklint. The two authors of this paper were involved in a Mutual Learning Exercise on Innovation-related Procurement, on which this paper is also based. This exercise was conducted under the Horizon 2020 Policy Support Facility, between January 2017 and March 2018 (Charles was the chairman and Jon Mikel was the rapporteur.) We are both obliged to Xavier van den Bosch, Viola Peter, Eva Buchinger, Gaynor Whyles and the other participants in this exercise. The authors are also grateful to the editor and the two anonymous reviewers for their feedback and the comments provided on earlier versions of the paper. Jon Mikel Zabala-Iturriagagoitia acknowledges financial support from the Basque Government Department of Education, Language Policy and Culture (IT 885-16) and Charles Edquist would like to acknowledge support from the Rausing Foundation.

\section{$\underline{\text { References }}$}

Abernathy, W.J., Utterback, J.M. (1978) 'Patterns of Industrial Innovation', Technology Review, 80(7): 41-47.

Aldenius, M., Khan, J. (2017) 'Strategic use of green public procurement in the bus sector: Challenges and opportunities', Journal of Cleaner Production, 164: 250-257.

Anderson, R.D., Kovacic, W.E. (2009) 'Competition Policy and International Trade Liberalisation: Essential Complements to Ensure Good Performance in Public Procurement Markets', Public Procurement Law Review, 18(2): 67-101.

Ang, G., Groosman, M., Scholten, N.P.M. (2005) 'Dutch performance-based approach to building regulations and public procurement', Building Research \& Information, 33(2): 107119.

Bergman, M.A., Lundberg, S. (2013) 'Tender evaluation and supplier selection methods in public procurement', Journal of Purchasing \& Supply Management, 19: 73-83.

Borrás, S., Edquist, C. (2013) 'The choice of innovation policy instruments', Technological Forecasting and Social Change, 80(8): 1513- 1522.

Borrás, S., Edquist, C. (2019) Holistic Innovation Policy: Theoretical Foundations, Policy Problems and Instrument Choices. Oxford, Oxford University Press.

Chicot, J., Matt, M. (2018) 'Public procurement of innovation: a review of rationales, designs, and contributions to grand challenges', Science and Public Policy, 45(4): 480-492. 
Crafts, N. (2018) 'The productivity slowdown: is it the 'new normal'?', Oxford Review of Economic Policy, 34(3): 443-460.

Czarnitzki, D., Hünermund, P., Moshgbar, N. (2018) Public Procurement as Policy Instrument for Innovation. ZEW Discussion Paper No. 18-001. Mannheim, Germany.

Diercks, G., Larsen, H., Steward, F. (2019) 'Transformative innovation policy: Addressing variety in an emerging policy paradigm', Research Policy, 48: 880-894.

Diggs, S.N., Roman, A.V. (2012) 'Understanding and Tracing Accountability in the Public Procurement Process', Public Performance \& Management Review, 36(2): 290-315.

Edler, J., Boon, W.P. (2018) 'The next generation of innovation policy: Directionality and the role of demand-oriented instruments - Introduction to the special section', Science and Public Policy, 45(4): 433-434.

Edler, J., Georghiou, L. (2007) 'Public procurement and innovation - Resurrecting the demand side', Research Policy, 36 (7): 949-963.

Edler, J., Ruhland, S., Hafner, S., Rigby, J., Georghiou, L., Hommen, L., Rolfstam, M., Edquist, C., Tsipouri, L., Papadakou, M. (2005) Innovation and public procurement. Review of issues at stake. ISI Fraunhofer Institute Systems and Innovation Research, Karlsruhe.

Edquist, C. (2014) Offentlig upphandling och innovation ("Public Procurement and Innovation" in Swedish. Swedish Competition Authority, Stockholm.

Edquist, C. (2015) Innovation-related Procurement as a Demand-Oriented Innovation Policy Instrument. CIRCLE Papers in Innovation Studies, Paper No 2015/28, Lund.

Edquist, C. (2017) Developing strategic frameworks for innovation related public procurement - Thematic Report Topic A of the Mutual Learning Exercise (MLE) Innovation related public procurement. European Commission, Directorate- General for Research \& Innovation, Directorate Policy Development and Coordination, Unit A.4 - Analysis and monitoring if national research and innovation policies. Available: https://rio.jrc.ec.europa.eu/en/policy-support-facility/mle-innovation-related-publicprocurement

Edquist, C. (2019a) 'Towards a holistic innovation policy: Can the Swedish National Innovation Council (NIC) be a role model?', Research Policy, 48(4): 869-879.

Edquist, C. (2019b) Funktionsupphandling för innovation, välfärd och miljö. (Functional public procurement for innovation, welfare and the environment - In Swedish, with 5-page summary in English). Konkurrensverket (Swedish Competition Agency). Uppdragsforskningsrapport 2019:2. Available: http://www.konkurrensverket.se/contentassets/916ecd96293549589d7ae5ee2e2c0eae/forskrapport 2019 2-.pdf

Edquist, C., Buchinger, E., Whyles, G., Zabala-Iturriagagoitia, J.M. (2018) Mutual Learning Exercise on Innovation-Related Procurement - Final Report. European Commission, Directorate- General for Research \& Innovation, Directorate Policy Development and Coordination, Unit A.4 - Analysis and monitoring if national research and innovation policies.

Edquist, C., Hommen, L., Tsipouri, L.J. (Eds.) (2000) Public technology procurement and innovation. London: Kluwer Academic Publishers.

Edquist, C., Vonortas, N., Zabala-Iturriagagoitia, J.M., Edler J. (Eds.) (2015) Public procurement for innovation. Cheltenham: Edward Elgar Publishing Ltd. 
Edquist, C., Zabala-Iturriagagoitia, J.M. (2012) 'Public procurement for innovation (PPI) as mission-oriented innovation policy', Research Policy, 41,(10): 1757-1769.

Edquist, C., Zabala-Iturriagagoitia, J.M. (2015) 'Pre-commercial procurement: A demand or supply policy instruments in relation to Innovation?', R\&D Management, 45(2): 147-160.

European Commission (2018) 'Commission notice. Guidance on Innovation Procurement', Brussels, 15.5.2018. C(2018) 3051 final.

European Union (2014) Directive 2014/24/EU of the European Parliament and of the Council of 26 February 2014 on public procurement and repealing Directive 2004/18/EC. European Parliament, Council of the European Union.

European Union (2015) ERAC Opinion on Innovation Procurement. ERAC 1209/15. Brussels, 23 June 2015.

Fagerberg, J. (2018) 'Mobilizing innovation for sustainability transitions: A comment on transformative innovation policy', Research Policy, 47: 1568-1576.

Fragkandreas, T. (2013) 'When Innovation Does Not Pay Off: Introducing the "European Regional Paradox"”, European Planning Studies, 21(12): 2078-2086.

Georghiou, L., Edler, J., Uyarra, E., Yeow, J. (2014) 'Policy instruments for public procurement of innovation: Choice, design and assessment', Technological Forecasting \& Social Change, 86: 1-12.

Hommen, L., Rolfstam, M. (2009) 'Public Procurement and Innovation: towards a taxonomy', Journal of Public Procurement, 9(1): 17-56.

Howlett, M. (2019) 'Moving policy implementation theory forward: A multiple streams/critical juncture approach', Public Policy and Administration, 34(4): 405-430.

Johansson, B., Lahtinen, M. (2013) 'Getting the balance right between functional and nonfunctional requirements: the case of requirement specification in IT procurement', International Journal of Information Systems and Project Management, 1(1): 5-16.

Kahlenborn, W., Moser, C., Frijdal, J., Essig, M (2010) Strategic use of public procurement in Europe. Final Report to the European Commission, MA RKT / 2010/02 / C. Berlin: Adelphi.

Kattel, R., Mazzucato, M. (2018) 'Mission-oriented innovation policy and dynamic capabilities in the public sector', Industrial and Corporate Change, 27(5): 787-801.

Knuttsson, H., Thomasson, A. (2014) 'Innovation in the Public Procurement Process: A study of the creation of innovation-friendly public procurement', Public Management Review, 16(2): 242-255.

Koivisto, J. (2018) 'Co-designing an outcome-based public procurement: Early involvements, participations and orderings', Journal of Public Procurement, 18(4): 323-335.

Lember, V., Kattel, R., Kalvet, T. (2014) Public Procurement, Innovation and Policy: International Perspectives. Heidelberg: Springer.

Martin, L.L. (2002) 'Performance-based contracting for human services: lessons for public procurement?', Journal of Public Procurement, 2(1), 55-71.

Mastroeni, M., Tait, J., Rosiello, A. (2013) 'Regional innovation policies in a globally connected environment', Science and Public Policy, 40(1): 8-16.

Mazzucato, M. (2018) 'Mission-oriented innovation policies: challenges and opportunities', Industrial and Corporate Change, 27(5): 803-815. 
McCrudden, C. (2004) 'Using Public Procurement to Achieve Social Outcomes', Natural Resources Forum, 28: 257-267.

Metcalfe, J.S. (1995) 'Technology systems and technology policy in an evolutionary framework', Cambridge Journal of Economics, 19: 25-46.

Neij, L. (2001) 'Methods of evaluating market transformation programmes: experience in Sweden', Energy Policy, 29: 67-79.

Obwegeser, N., Müller, S.D. (2018) 'Innovation and public procurement: Terminology, concepts, and applications', Technovation, 74: 1-17.

OECD (2016) Public Procurement for Innovation: Good Practices and Strategies. Paris: OECD.

OECD (2017) Government at a Glance 2017. Paris: OECD.

OECD/Eurostat (2018) Oslo Manual 2018: Guidelines for Collecting, Reporting and Using Data on Innovation. 4th Edition, The Measurement of Scientific, Technological and Innovation Activities, OECD Publishing, Paris/Eurostat, Luxembourg.

Palmberg, C. (2006) 'The sources and success of innovations - Determinants of commercialisation and break-even times', Technovation, 26: 1253-1267.

Popper, K. (1957) "Preface" in The Poverty of Historicism. Routledge.

Rolfstam, M. (2013) Public procurement and innovation. Cheltenham: Edward Elgar Publishing.

Schot, J., Steinmueller, W.E. (2018) 'Three frames for innovation policy: R\&D, systems of innovation and transformative change', Research Policy, 47(9): 1554-1567.

SFS (2016) 'Lag (2016:1145) om offentlig upphandling' - LOU, (Law on Public Procurement). Stockholm: Socialdepartementet.

Strumsky, D., Lobo, J., Tainter, J. (2010) 'Complexity and the Productivity of Innovation', Systems Research and Behavioral Science, 27: 496-509.

Suchman, M.C., Eyre, D.P. (1992) 'Military Procurement as Rational Myth: Notes on the Social Construction of Weapons Proliferation', Sociological Forum, 7(1): 137-161.

Suman, M. (2006) 'Weapons Procurement: Qualitative Requirements and Transparency in Evaluation', Strategic Analysis, 30(4): 724-744.

Timmermans, B., Zabala-Iturriagagoitia, J.M. (2013) 'Coordinated unbundling: A way to stimulate entrepreneurship through public procurement for innovation', Science and Public Policy, 40(5): 674-685.

Tysseland, B.E. (2008) 'Life cycle cost based procurement decisions: A case study of Norwegian Defence Procurement projects', International Journal of Project Management, 26(4): 366-375.

Uyarra, E., Flanagan, K. (2010) 'Understanding the innovation impacts of public procurement', European Planning Studies, 18(1): 123-143.

Uyarra, E., Edler, J., Garcia-Estevez, J., Georghiou, L., Yeow, J. (2014) 'Barriers to Innovation through Public Procurement: A Supplier Perspective', Technovation, 34(10): 631645. 
Uyarra, E., Zabala-Iturriagagoitia, J.M., Flanagan, K., Magro, E. (2020) 'Public procurement, innovation and industrial policy: rationales, roles, capabilities and implementation', Research Policy, 49(1): 103844.

van den Hove, S., McGlade, J., Mottet, P., Depledge, M.H. (2012) 'The innovation union: A perfect means to confused ends?', Environmental Science \& Policy, 16: 73-80. 